DOI https://doi.org/10.18551/rjoas.2017-12.12

\title{
THE BUDGET ANALYSIS OF THE REGION'S DEVELOPMENT TRENDS
}

\author{
Astakhova E. ${ }^{*}$, Candidate of Economic Sciences \\ Vladivostok State University of Economics and Service, Vladivostok, Russia
}

\author{
Alekseeva N., Specialist \\ Apriori-Consulting Ltd, Vladivostok, Russia \\ *E-mail: evastahova1@yandex.ru
}

\begin{abstract}
Financial basis of state authorities and local self-governments in the social and economic development is the country's budget system. The budgetary policy planning, first of all should take into account attention to ensuring financial and social stability. One of the components of the budget system of the Russian Federation is the local budget. The main purpose of the local budget is to accumulate financial resources that come from various sources eliminating management. This article is an analysis of the Vladivostok City's structure and dynamics of revenues and expenditures of the budget for the period of 2014-2016.
\end{abstract}

\section{KEY WORDS}

Municipal budget, budget process, budget revenues, budget expenditures, deficit, surplus.

The purpose of budgets is variously referred to as financial plans, work plans or programs, or political and social documents. In its strictest, most technical sense, a budget is a document containing words and figures that propose expenditures for certain items and purposes. The words describe items of expenditure or purposes and figures are attached to each item or purpose. The budget has also been defined as a process consisting of a series of activities relating expenditures to a set of goals, or as a process through which public expenditures are undertaken. While considerations of revenue constraints and taxation are inherent in the budget process, within the context of parliamentary work, budgeting is generally treated as part of the expenditure process, rather than as a revenue raising process. In this respect, public budgeting serves as the allocation of expenditures among different purposes so as to achieve the greatest results. A budget can be viewed from various frames of reference. These are:

- Political process - competition among various groups for limited resources. The allocation of the budget is a key instrument for government to promote economic development efficiently. The budget allocation process is a political issue, and understanding the institutional and political context in which budget decisions are made and implemented is critical for achieving better outcomes. The national budget is a representation, in monetary terms, of governmental activity. The budget serves as a tool for government activities towards the achievement of its priorities.

- Economic process - resource allocation. The budget is the most important economic instrument of the government, as it reflects the country's socio-economic policy priorities by translating priorities and political commitments into expenditures. In this way, the budget emphasizes constraints and trade-offs in policy choices. Government budgets play an essential role in the planning and control of the economic activities of a nation. Three central economic functions of the government budget are:

- Allocation of resources. This function relates to the provision of public goods and services by the government. All the goods and services in a country are produced either by government, by the various economic sectors in that society, and by household sectors. In allocating resources, government must decide both the relative size of public service provision, as well as how available resources are divided among the various government functions e.g. social development, health, and defense, policies and programs. Allocations to 
certain functions, policies and programs might benefit some groups, particularly vulnerable groups, more than others. Analysis of the budget seeks to uncover the allocation consequences of budgets.

Distribution of income and wealth budgetary policy can be used to attempt to redress inequalities in income and wealth distribution. The government's concern could relate to inequalities between various groups and sectors of society. Budgets are premised on the assumption that a 'fair' and equitable distribution between all groups of society is an important goal. Stabilization of the economy Government budgets are used to promote a certain level of employment, stability in prices, economic growth, environmental sustainability and external balance. Stabilization policy requires economic, political, and social judgments in determining, for example, which objective has priority at any one time, as well as what the acceptable levels of unemployment, debt, and interest rates are, and so forth. Budgetary policy can encourage sustainable economic growth through the planning potential of the budget. In addition, government budgets are both a means of ensuring that governments are accountable to Parliament for their revenues and expenditures; as well as a measure by which governments can maintain control over their finances. Budget analysis requires an understanding of the macroeconomic constraints, assumptions and theories that underpin the budget. The budget itself is a means to achieve objectives. Therefore, the first task in drawing up budgets is to determine objectives and the policies that are likely to achieve these objectives. Budgets should follow policy, rather than vice versa.

Budget analysis is a thorough and detailed review of the budget. It involves the collection, study and interpretation of budget data, the correlation of budget data to other relevant information such as State policies and programs, and the establishment of findings and results. Its aim is to provide analysis and information that is credible, accessible, and makes a timely contribution to policy debates, with the purpose of affecting the manner in which budget issues are decided and decisions are made. Budget analysis is undertaken through a number of perspectives. Some groups assess financial arrangements covering national and sub-national goals. The effects of budget decisions on programs that affect vulnerable sectors, while others study the relationship of spending for one function against another (for example, military spending or debt service compared with economic development). Still others analyze budget process issues, policies and institutions. Other groups undertake budget analysis through a very technical lens; this includes classifying expenditures by major and minor headings (function or nature of expense), looking at budget figures, studying new allocation items, and understanding the government's development plans as expressed by budgetary allocations. Getting started on budget analysis involves a four-step process.

Budget analysis requires an understanding of public administration processes. This is essential in order to have a proper perspective on why events unfold as they do, and to provide the best possible analysis of budgets and budget requests. In conducting a budget analysis, it is important to understand the programs of the department or agency, and the processes involved in carrying out the department's mission, and how they relate to other government functions. It is also important to know how to effectively communicate detailed information, which in many instances is perceived as negative feedback. The budget process or budgeting refers to the process by which governments create and approve a budget. This implies that when crafting the overall budget authorities take a medium-term (three years) outlook. The forthcoming year is the official budget year, while the two outer-years serve as baselines or indicators for the upcoming budgets. In summary, Parliament votes only on the forthcoming year not the two outer years.

The budget cycle comprises the major events involved in making decisions about the budget, and implementing and assessing those decisions. The specific characteristics of the budget cycle differ from country to country. Generally, the budget cycle is likely to have four stages. Many different and individual decisions have to be made at many different levels. National government must decide how much of the share of nationally raised revenue is allocated to national, provincial and local government. National, provincial and local governments must each decide how to divide their budgets between different departments. 
Within departments, decisions are made on how much is spent on different programs. These events go through the various cycles of the budget process.

The traditional approach to budgeting is that it is done on an annual basis. Such an approach has the potential to isolate the budget cycle from macroeconomic factors, expectations on future revenue, the long-term needs of programs and government's spending priorities. Any approach to budgeting which has the achievement of efficiency, fiscal discipline and operational efficiency as important objectives would follow a multi-year budgeting approach. In a multi-year budgeting approach, the current financial year informs the budgetary decisions for the upcoming budget year, and the estimates of the budget year provide an indication of longer term estimates for the outer years.

In many countries a significant share of government expenditures is managed through special procedures. These special arrangements include: revolving funds to provide more flexibility in government spending, notably to overcome the annual rule; trading funds for departmental enterprises and other commercial services rendered by the government; emergency funds; special funds for specific expenditure purpose $s[$ such as road funds, health funds] managed at the sector level; expenditures financed by external loans; counterpart funds; budgets of autonomous/decentralized agencies, notably in the highereducation and health sectors; and special accounts managed by the Ministry of Finance or its Treasury Department.

In 2014 , the total non-tax revenues share is $49.5 \%$. This indicator is higher than the share of non-tax revenues. $28.4 \%$ of budget revenues come from taxes on profits, which are of paramount importance for the growth of all tax revenues, $12.1 \%$ contribute taxes to property on a common basis, they also play a big role. The least of all tax revenues are the State duty and taxes on goods. Among non-tax revenues, a larger amount of funds is made from the use of property in state and municipal ownership, which account for $10.8 \%$ [ 7]. In the budget of Vladivostok, $5.6 \%$ yield revenues from the sale of tangible and intangible assets.

Among non-tax revenues, small amounts of funds fall on payments that are paid using natural resources and other non-tax revenues. Among gratuitous receipts in the budget in the greater volume the incomes arriving in the form of $30 \%$ of gratuitous receipts from other budgets are charged. It can be seen that the budget of Vladivostok city district fundamental types of revenues in 2014 were tax revenues and gratuitous receipts, which are part of, or $29.8 \%$ of total revenues [1].Fundamental incomes in Vladivostok are taxes on profits, b repayments from other budgets budgetary system of the Russian Federation. Also great weight is the tax on property and income from the use of property in state and municipal ownership.

In 2015, the same uncompensated receipts from other budgets and income taxes, as well as property taxes and income from the use of property in state and municipal ownership, were the basic revenues of the Vladivostok urban district budget. However, there were changes in the total weight of incomes. Tax revenues, which are almost half of budget revenues, slightly decreased its rate amounted to $49.3 \%$. Non-tax revenues, on the contrary, increased their share in the total amount of budget revenues, having increased in comparison with the previous period and amounted to $20.9 \%$. Gratuitous receipts as well as tax revenues decreased in specific weight, by $0.1 \%$.

Thus, tax revenues continued to play a major role in the replenishment of the city's budget. Among tax revenues, income taxes increased in their specific weight by $1.3 \%$. All other tax revenues reduced their share. The second most profitable tax revenue, property tax suffered a decline of $0.9 \%$. The main income among non-tax revenues, income from the use of property in state and municipal ownership, fell this year by $0.2 \%$ and amounted to $10.6 \%$. Revenues from the sale of tangible and intangible assets increased their share. Among gratuitous receipts, gratuitous receipts from other budgets decreased in their specific weight by $0.1 \%$.

In 2016, the situation was not radically changed. However, now it has become, so more than half of the volume of funds began to be occupied by non-tax revenues. Their share was $53.1 \%$. The share of non-tax revenues decreased to $19 \%$ compared with two last year's 
periods. Gratuitous income also decreased in percentage terms. Their decrease was $2 \%$, this decline in gratuitous revenues is the biggest in two years. Among tax revenues, income taxes in 2016 amounted to the highest value, amounting to $31 \%$, and for the entire period this tax has constantly increased its share. Despite the decrease in the share of property tax in 2015 , it increased its share by $1.7 \%$ and brought $12.9 \%$ of revenues to the budget of Vladivostok urban district, which is higher than the rates of the previous two periods. As for non-repayable receipts, they continued to decline after the decrease in gratuitous revenues from other budgets, which declined in three years to $27.8 \%$. Revenues from the sale of tangible and intangible assets gained the highest share in 2015. A large share of gratuitous revenues took place in 2014, and in 2016 it was the lowest.

Income taxes, property taxes and the tax on aggregate income also had the lowest in 2015 and the highest in 2016. Non-tax revenues, on the contrary, had the largest share in 2015 and the lowest in 2016. But the income from the use of property located in state and municipal property had the highest share in 2014 . So, the largest share of tax revenues was in 2016, non-tax income was in 2015, and gratuitous proceeds in 2014.

In 2015, the tax revenues received in the Vladivostok city budget exceeded the previous year indicator by $12.7 \%$ in the amount of 665 million rubles. Due to increasing all tax revenues, except for arrears and recalculations for canceled taxes, fees and other mandatory payments. Taxes on profit, increasing by 558 million rubles to $18.6 \%$, had the largest increase. Taxes on property increased 65.9 million rubles, while taxes on aggregate income increased by 26.5 million, state duty increased by $9 \%$, but the least of all increased taxes on goods sold in the territory of the Russian Federation in the amount of 2.7 million rubles.

The growth of non-tax revenues in this period amounted to $15.6 \%$, which in monetary terms amounted to 338.9 million rubles. This was the receipt of income in excess of the previous period of all incomes, except for other non-tax revenues. 130.8 million rubles is the largest increase in the proceeds from income from the use of property in state and municipal ownership. The sale income is from the tangible and intangible assets and is increased by 117.4 million. The largest percentage ratio increase was $44.5 \%$ of revenues from the paid services provision and compensation for state expenses. On the contrary, other non-tax revenues received an amount reduced by $7.5 \%$

The situation has been changed in 2016 for non-tax revenues and donations. Tax revenues, however, again brought in the amount that exceeded the indicator of 2015 . This time the difference was 671 million rubles, which is higher than the previous year. As before, taxes on profits had the highest absolute deviation from all tax revenues, but it was $10.6 \%$ lower than the previous year's figure. Taxes in this period brought income increased by 257.2 million, which is significantly higher than in 2015 . The same trend has a tax on aggregate income. Taxes on goods increased by $63.3 \%$, on the contrary, the revenue from state duty was lower by $14.4 \%$.

Non-tax revenues brought in 2016 funds that were lower than in the previous world by 151.6 million rubles and higher than in 2014. The size of the decline was $6.1 \%$. This was due to lower non-tax income indicators, with the exception of others and fines. The largest decrease in income from the sale of tangible and intangible assets, amounting to 113.4 million rubles, as well as income from the provision of paid services and state compensation equal to $48.4 \%$.

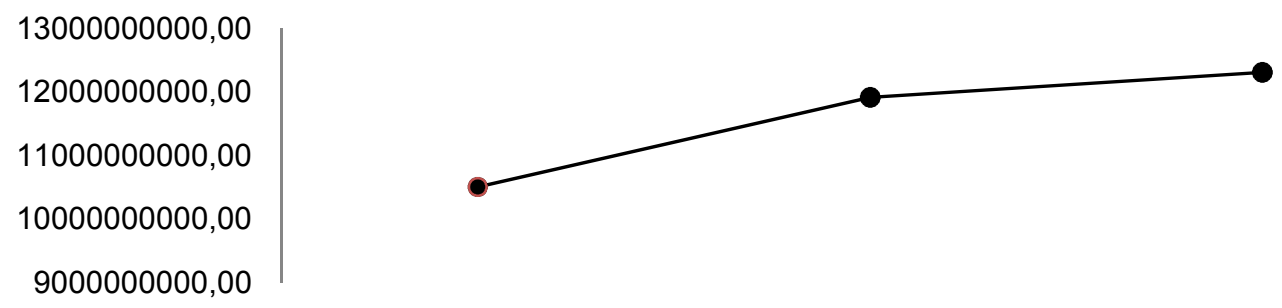

Figure 1 - Income budget flow, Vladivostok region (2014-2016) 
It is showed a clear tendency to increase the key figure. Every year, the number of funds coming to the budget in the form of revenues gained weight. This indicates a positive trend in revenue growth budget Vladivostok urban district. The revenues of the Russian Federation budget system from the budgets return of the remnants of subsidies, subventions and other transfers that have a designated purpose, of the past years decreased by $37 \%$. This is a record percentage increase for the entire period among all budget revenues of the Vladivostok urban district. Tax revenues had a larger increase in income in 2016 due to the growth of income tax, property tax, the tax on aggregate income and taxes on goods sold on the territory of the Russian Federation. Due to budget constraints, it is necessary to distribute the collected revenues efficiently and optimally [ 8]. In 2014 in Vladivostok city district a large share of funds was spent on education. It reached half of all budget funds spent without $3.1 \%$. Also, the Vladivostok budget is aimed at spending the national economy, which amounted to $16.3 \%$. State-wide issues demanded $14.6 \%$ of expenditures, $12.9 \%$ for housing and communal services, and $3.9 \%$ spent on servicing state and municipal debt. For health this year, funds were not spent. The least money spent on environmental protection, namely $0.04 \%$. National security and law enforcement, physical culture and sports, culture and cinematography, as well as social policy were no more than $1.5 \%$.

In 2015, as in the previous period, education accounted for a large share of expenditures. However, its share fell to $46.5 \%$. Expenditures on the national economy also declined, but by $0.6 \%$. The share of national issues in the amount of $0.1 \%$ has decreased. State expenditures amounted to $14.5 \%$, which is also lower than the previous indicator. Expenditure on housing and communal services, on the contrary, this year increased its share to $13.5 \%$. Environmental protection, with a smaller share of funds, had a slight increase. The service of state and municipal debt, culture and cinematography, and social policy also increased.

In 2016, the situation was not radically changed. The structure of expenditure still looked so that funding for education clearly prevailed [15]. However, during the whole period, the specific gravity decreased. It amounted to $46.3 \%$, thereby decreasing by $0.6 \%$ as compared to 2014 , and $0.2 \%$ by 2015 . Expenditures on the national economy amounted to $16.4 \%$, which is higher than in the previous two periods. Also increased and exceeded the performance of the past two years, the costs of solving national problems. Housing and communal services, which accounted for a lower indicator than in the past, fell by $2 \%$ compared to 2015 , when the indicator was the largest; this decrease is the highest in all areas of expenditure.

Thus, for the period 2014-2016, a significant share in the budget expenditures is the expenditure used for the education sector. They make up the bulk of the funds and reach almost half of the funds. Also, budget expenditures are mainly directed to the national economy, national issues and housing and communal services. This suggests that budget expenditures have a socio-economic focus, which positively affects the development of the social infrastructure of society [11].

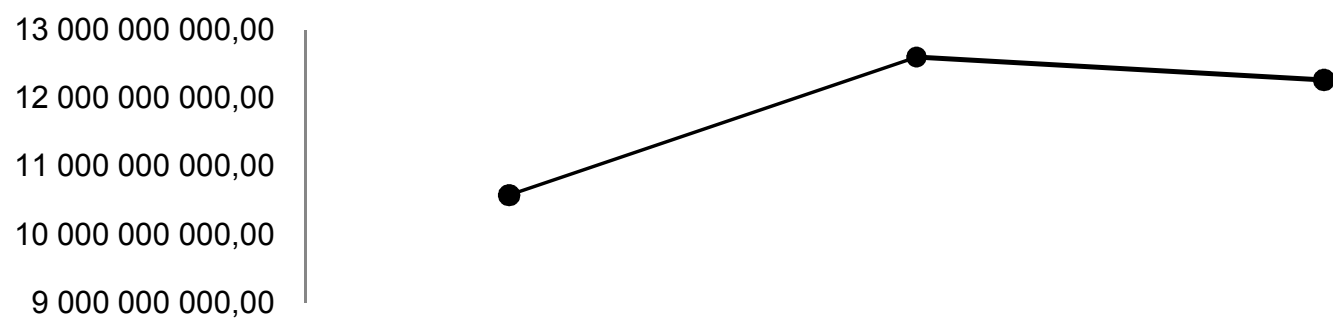

Figure 2 - Expenditures budget flow, Vladivostok region (2014-2016)

The budget expenditures of the city of Vladivostok in 2015 increased compared to the previous year, but the following year this trend changed and expenditures were reduced. Vladivostok City District allocated budget funds for solving problems related to the state 
infrastructure more comprehensive development of the district. The very development of the district depends on the state of education, health, culture, physical culture and sports, business environment, housing and the environment.

In 2015, the budget expenditures of Vladivostok urban district increased by 2.02 billion rubles, which reached $19.1 \%$. The greatest growth was in the sphere of education. Expenses for them were increased in the amount of 902.2 million rubles, which amounted to $18.1 \%$. This year, expenditures for housing and communal services are increased by 345.2 million. Expenditures on national issues are increased by $18.6 \%$, and expenditures on the national economy - in the amount of $14.9 \%$. The protection of the environment, which uses the lowest sums of money in Vladivostok, increased $123 \%$ in this period. This is the highest percentage increase, but the amount was only 5.6 million rubles.

In 2016, the situation with the amount of spending was changed. Expenditures of the budget decreased compared to last year's period by 332.7 million rubles. There was a decrease in the expenditure direction itself, the sphere of education by 181.8 million, which amounted to $3.1 \%$. For a large amount of money, expenditures on housing and communal services decreased when, as last time, they had the second largest increase. The highest decrease is $17.5 \%$ [14].

In conclusion, the revenue base of the district is replenished mainly due to tax revenues, as well as gratuitous receipts. The main taxes yielding income were income tax, property tax, as well as income from the use of property in state and municipal ownership and gratuitous income from other budgets of the budgetary system of the Russian Federation. The main areas of expenditure for the Vladivostok city district budget were education, the national economy, national issues and housing and communal services.

As a result of budget execution, the Vladivostok City District managed to break out of the budget deficit, due to exceeding budget revenues that increased in volume, over expenditures that were otherwise reduced. This situation developed in 2016. This year not only managed to get rid of the deficit, but also to achieve a budget surplus. All this speaks about the effectiveness of the budgetary policy of the district.

Despite the fact that the Vladivostok city district does not include the number of central cities in Russia, but it has a powerful and developed economy, as well as a huge economic potential. Vladivostok is a city that is full of boundless opportunities for development, and this can and should be used.

Moreover, for today Vladivostok is becoming a new center of the modern economy of the Asia-Pacific region and in the future a number of large projects will be implemented, as a result of which there will be even more potential for the development of Vladivostok urban district.

\section{REFERENCES}

1. Antonova N.L, Pavlova A.D. Optimization of increase in incomes and reduction of expenses of local budgets of the Khanty-Mansiysk Autonomous Okrug Yugra on the example of Surgut // Proceedings of the SIC Sotsiosfera. 2015. №47. pp. 28-32.

2. Baginova V.M., Golova A.S. Revenues of local budgets on the example of the urban district "Ulan-Ude city" // Actual problems of modern economy, collection of scientific papers. Ser. «Economic sciences». 2016. P. 15-19.

3. Astakhov V.V. Instrumental and technological directions to ensure economic security of enterprise // Int. Review of Management and Marketing. 2016. №S1. pp. 172-178.

4. Bondarenko T.N. Tax collection as an instrument of replenishment of local budgets by the example of Artemovsky urban district of the Primorye Territory // Modern scientific research and innovations. 2015. №7-3. pp. 36-41.

5. Astakhova K.V. The role of education in economic and social development of the country//International Review of Management and Marketing. 2016. №S1. pp. 53-58.

6. Vorobyeva L.T. Problems of planning of incomes and expenditures of local budgets // Finances and credit. 2010. №32. pp. 65-73. 
7. Vorozhbit O.Y., Litvin A.A. Introduction of the tax on immovable property of individuals in Vladivostok city district // Fundamental research. 2014. №9-4. pp. 813-817.

8. Vorozhbit O.Y. Analysis of the structure and dynamics of expenditures of the Vladivostok urban district // Actual questions of economic sciences. 2015. №42. pp. 149-153.

9. Govorushina T.K. Formation of incomes of budgets of municipal formations // XVIII Tsarskoye Selo readings. 2014. pp. 84-88.

10. Gryaznova A.G. Finance. Moscow: Finance and Statistics, 2012. 496 p.

11. Lagunova, T.P. On incomes of local budgets. // Bulletin of the State Technical University. M.T. Kalashnikov. 2014. №3. pp. 75-77.

12. Naydenova T.A. Non-tax revenues of budgets of municipalities as a factor to increase the stability of local budgets // Actual problems of the humanities and natural sciences. 2016. №10-1. pp. 206-211.

13. Polyak G.B. Budget Law. Moscow: Unity-Dana, 2012. 287 p.

14. Rogova T.A, Utkina A.V. Features of income generation and financing of the budget expenditures of the Vyaznikovsky municipal district of the Vladimir region // Bulletin of the Vladimir State University. Series: Economic sciences. 2016. №2. pp. 6-10.

15. Sumskaya T.V. Evaluation of the main directions of the budget policy in the city of Novosibirsk // Interexpo Geo-Siberia. 2015. №2. pp. 19-25.

16. Harisova E.V. The role of local taxes in local budgets. On the example of the largest urban districts of Nizhnevartovsk and Surgut // Energy of Science, 2016. pp. 361-364. 